Forthcoming in Toleration and the Challenges of Liberalism. Eds. Johannes Drerup and Gottfried Schweiger. Routledge.

*This is a pre-print page-proof version

6

\title{
Liberalism and Toleration
}

Jon Mahoney

\begin{tabular}{|l|}
\hline Abstract \\
Political liberty is at the centre of liberal conceptions of toleration. \\
Liberal political philosophers disagree about the limits of toleration, \\
whether equality is central to liberal toleration, and the toleration of \\
illiberal religious and cultural practices, among other topics. Some \\
non-liberal states adopt a model of toleration, despite significant \\
limitations on liberty. Moreover, some recent work in comparative \\
philosophy emphasizes pluralism across traditions of political morality. \\
This chapter will consider a variety of positions on liberal toleration as \\
well as the challenge to liberal toleration posed by ethical pluralism. \\
Key Words: Liberalism, Toleration, Liberty, Equality, Pluralism \\
\hline
\end{tabular}

Introduction

Toleration is fundamental to liberalism. Yet liberal political philosophers do not agree about the justification for toleration, the limits of toleration or whether every society is obligated to adopt a liberal conception of toleration. Does toleration depend on the harm principle (Mill, 1978)? Does liberal toleration depend on a basic right to justification (Forst, 2013)? Does a principle of toleration apply to political philosophy itself (Rawls, 1996)? Does liberal toleration require accommodating illiberal practices within liberal states? Is liberal toleration compatible with gender-egalitarian policies designed to make it harder for certain marriage and family practices to persist (Schouten, 2019)? What is the relation between toleration and neutrality (Balint, 2017)? Do those who affirm a collectivistic conception of political morality have an obligation to meet the requirements of a liberal conception of toleration? These and other questions generate disagreement about liberal toleration. Liberals continue to debate these and related topics about the basis for toleration, and how we should treat one another within and across diverse societies. In 
some ways debates about toleration are similar to debates about liberty and equality: shared concepts do not entail shared conceptions.

Some ideas unite competing conceptions of toleration (Forst, 2017). One is that to tolerate is to be willing to permit something one opposes. Another is that political liberty is a moral basis for toleration. The first agreement point - that to tolerate is to be willing to permit some things one finds objectionable - is central to the very idea of toleration. The second agreement point - that political liberty requires toleration - is central to liberalism. Putting the two together, we can characterize, in abstract, the fundamental idea behind liberal conceptions of toleration as follows: citizens and government should affirm a right to liberty and in doing so respect the diversity and pluralism that respect for liberty permits. There are important debates about which conception of liberty is most appropriate, whether political values such as equality should inform liberal toleration or whether the individualism that informs liberal political morality is a bias that reflects dominant western religious and cultural identities. Yet common ground - liberty is a primary basis for toleration - and the disputed ground - applications, universalism and limits - can be stated in this way.

This chapter will consider liberalism and toleration with three issues in focus: liberal and non-liberal conceptions of toleration, toleration and equality, and toleration and pluralism. First, it adapts ideas from Rainer Forst's taxonomy (2013, 2017) of conceptions of toleration. Non-liberal conceptions of toleration will be briefly considered as well. Second, it examines some ways that equality in status is relevant to liberal toleration. Being a Muslim American and being a Protestant American correlate with different social statuses, irrespective of an official state policy of religious equality. This is relevant to questions about liberal toleration. Third, it considers pluralism as a challenge to liberal toleration. When considering toleration from the standpoint of comparative or global philosophy some traditional liberal convictions about political morality may be harder to maintain. Finally, I conclude with a proposal to explore new ways that liberal political philosophers can approach toleration.

\section{Varieties of Toleration: Conceptions and Practices}

Toleration does not depend on liberal political values. Liberty as a moral basis for toleration is something that distinguishes liberal from non-liberal conceptions of toleration. A conception of toleration that does not rest upon the idea of a fundamental right to liberty is non-liberal. Two examples of non-liberal conceptions of toleration are coexistence and permission (Forst, 2013, pp. 27-29).

Illiberal Toleration. Religious, ethnic or cultural groups might accept a principle of toleration because they believe that coexistence is preferable to violence. The Hobbesian principle, "seek peace if others are willing to seek peace" can serve as the basis for a coexistence practice of toleration. In some contexts, this might be the most feasible alternative to significant hostilities. For example, following a long and protracted conflict, members of different religious, ethnic or cultural groups who are unwilling to affirm a principle of liberty might be willing to accept a kind of modus vivendi as preferable to open hostilities and conflict.

Some authoritarian states enact another kind of non-liberal toleration. For example, a hegemonic state might grant minority groups permission to practise a religion, speak a minority language or maintain a cultural practice conditioned on loyalty to the state and acceptance of official status inequalities. The Ottoman state policy of imposing lower tax 
burdens on Muslims while permitting Greek and Armenian Christian religious practices is an example of the permission conception of toleration. The Ottoman millet system also granted individual millets the authority to adopt their own marriage and family law along with limited autonomy in some other areas of life. Official inequality in status between privileged subjects and other groups is one way that this permission model of toleration differs from a liberal model. As with coexistence, the permission conception does not presuppose political liberty. Nevertheless, the permission conception does represent a form of toleration as can be shown by contrasting it with the oppression and intolerance within other kinds of authoritarian regimes.

By contrast with the Ottoman millet system, current Chinese policy in contemporary Xinjiang province is designed to force-assimilate Uighurs into an imagined national identity (Jacobs, 2017). This is just oppression. State policy directed at the language, culture, or religion of its own population, with the aim to radically reshape the group's identity, is a kind of internal colonialism. Forced-assimilation was not the aim of the Ottoman millet system. In that respect treatment of Greek Orthodox and other groups is an example the permission conception of toleration.

Coexistence and permission count as a form of toleration without liberty in the sense that groups of religious or cultural minorities are accommodated, but not on the basis of fundamental political rights. A regime based on one of these conceptions of toleration will be deficient according to a liberal perspective on toleration.

Some liberal states treat religious minorities in ways that violate standard norms of liberal tolerance. Sometimes minority groups face persecution within liberal states to a greater extent than in non-liberal states. Liberal states founded by settler colonists, such as the US and Australia, treated indigenous minority groups with extreme intolerance. Internal colonialism is not unique to illiberal states. Both policies and treatment of Native Americans in the nineteenth century was genocidal; the Ottoman millet system was not. Sometimes liberal states adopt intolerant policies towards some groups, and sometimes citizens in liberal states are not prevented from harming unpopular groups. Mormons in the nineteenth century, and Jehovah's Witness in the early twentieth century, were subject to significant hostilities by both citizens and state actors in the US. Violence against Jehovah's Witness in early-twentieth-century America involved mobs who attacked a religious minority they believed were disloyal Americans and whose understanding of Christianity differed from the mainline Protestant identity reflected in the majority religious identity (Smith, 2015, pp. 119-150). An account of toleration should be able to reckon with these and many other kinds of cases.

Liberal Toleration. A liberal conception of toleration will affirm liberty as a fundamental value. On a liberal view, toleration is required by liberty. Peter Balint expresses the basic idea behind a liberal position on toleration that is endorsed by liberals ranging from Mill to Rawls and many others: "I take it as a fundamental tenet of liberalism that it is interference, rather than non-interference that must be justified" (Balint, 2017, p. 11). On the view toleration is required by political liberty, including freedom of religion, expression and association. Liberty is the basis for the respect conception of toleration (Forst, 2013, pp. 29-30). Forst calls this the respect conception and by doing so refers to a set of views on liberal toleration according to which affirming individual liberties, such as freedom of thought or liberty of conscience, is an important moral basis for toleration.

To illustrate the respect conception, let's consider an example from American case law. In West VA v Barnette (1943) the Court ruled on whether children in a public school can be compelled to affirm a pledge to the American flag. Even today many American citizens 
support a practice of requiring children in public schools to recite a pledge to the civic and political values widely believed to be central to American national identity (Rasmussen Reports, 2013). On this view, a mandatory pledge of allegiance does not violate neutrality. By contrast, were a public school to require students to participate in a religious ritual, or to affirm a religious viewpoint, many citizens would agree that this violates neutrality, and also the liberty of conscience affirmed by the First Amendment. The main idea is this: whereas a mandatory religious service for children in public schools would compel a citizen to endorse a religious viewpoint in violation of religious neutrality, a political or civic ritual affirming the shared bases for citizenship does not violate neutrality in the relevant sense. It matters that Barnette was decided in 1943, before the phrase "one nation under God" was added to the pledge of allegiance. That phrase was added in 1954 (Shiffrin and Blasi, 2009). We can refer to the pre-1954 version as a secular-political pledge.

Is it intolerant for a liberal state to compel students in a public school to assert a secularpolitical pledge of the sort challenged in Barnette? In the early twentieth century, some Jehovah's Witness opposed the mandatory pledge in public schools claiming the policy requires their children to engage in a kind of idolatry. Since the prohibition on idolatry is a religious obligation, the mandatory secular-pledge, according to this view, requires children to disavow a core principle of their religious faith. Whereas an oath to God is a matter of religious duty, the mandatory pledge is compelled by a secular state, and so it constitutes a pledge to a political not religious authority. We can imagine other, similar claims. For example, suppose a Muslim parent objected to the pledge on grounds that Islam requires Muslims to affirm a principle of monotheism according to which, "there is no God but God". Suppose the Muslim parent insisted that a mandatory pledge puts the state and its education policy between her child and God, forcing a student to choose between a religious obligation and an official state policy. We can also imagine a secular citizen claiming it is a violation of liberty to compel citizens to participate in a mandatory loyalty ritual. In addition to the social stigma of non-conformity to a mass loyalty ritual, the injury to liberty of conscience, whether religious or secular, is a serious consideration this case.

Although in Barnette the Court did not consider the hypothetical cases of a Muslim or a non-religious opponent to the mandatory pledge in public schools, both the real and hypothetical examples show how a mandatory pledge of this sort might be objectionable to some citizens. Since liberty is the basis for a respect conception of toleration, we need to unpack the idea of liberty to see how a liberal conception of toleration might handle cases like this one.

Seanna Shiffrin's "thinker-based approach" (Shiffrin, 2011) to liberty of thought offers a perspicuous account of why a case like Barnette is not a debate over trifles. In an insightful passage, Shiffrin summarizes some of the moral dimensions to liberty of thought, with $W V v$. Barnette in view:

What seems most troubling about the compelled pledge is that the motive behind the regulation, and the possible effect, is to interfere with the autonomous thought processes of the compelled speaker. Significantly, the compelled speaker is also a compelled listener and is compelled to adopt postures that typically connote identification with her message. The aim, and I believe the potential effect, is to try to influence the speaker to associate herself with the message and implicitly to accept it, but through means that bypass the deliberative faculties of the agent. Compelled speech of this kind threatens (or at least aims) to interfere with free thinking processes of the speaker/listener and to influence mental content in ways 
Error! No text of specified style in document. Liberalism and Toleration

and through methods that are illicit: nontransparent, via repetition, and through coercive manipulation of a character virtue, namely that of sincerity, that itself is closely connected to commitments of freedom of speech. (Shiffrin, 2011, p. 302)

On this view, the mandatory pledge is a violation of freedom of thought. The practice cannot be reconciled to the idea of respect for liberty at the heart of a liberal regime that professes a commitment to toleration.

The thinker-based approach to freedom of expression provides a compelling illustration of why liberty of thought is important to individuals. In doing so it highlights something that is fundamental to the liberty that a conception of liberal toleration is supposed to protect: freedom of thought, a fundamental interest that persons have to express their agency without coercive interference. Liberty on this view is inclusive of freedom of association and freedom of religion, among other freedoms.

Whether aligned with a thinker-based approach or some other liberal conception of liberty, a respect conception of toleration can side with those who oppose a mandatory pledge, like the one in dispute in Barnette. That kind of compelled loyalty oath in the face of a religious or other value-based objection, is a form of intolerance. It denies someone the liberty of thought that is at the base of liberal political morality. It is a harder question to decide which forms of political loyalty are legitimately enforceable and by what means such loyalty may be enforced. For example, judges or politicians take an oath as a condition for serving in an official capacity. In the US citizens cannot be compelled to take an oath on the basis of a religious doctrine, because the Constitution prohibits a religious test as a condition for public office. Yet public servants can be required to take a political oath.

Is it unreasonable from the standpoint of toleration to require police and many other agents of the state to take an oath to comply with norms governing their professional obligations as agents of the state? An agent of the state has a different status, legally and morally, than a subject of a state. Legally, because the state authorizes their power; morally, because their legally authorized power is exercised on citizens. Agents of the state are still citizens of course, so policies that govern this area must serve multiple aims. One is to guarantee that the policing authority of government reflects legitimate political values, rather than the private judgment of the public servant. Another is to refrain from curtailing the liberty of public servants in their official capacities beyond what is necessary to maintain the first aim. If we grant this perspective, we can say that as an agent of the state one's role is defined by the political authority the agent represents. The liberty at the root of toleration applies foremost to citizens exercising their own judgments on behalf of their own views.

The respect conception of toleration is well suited to handle conflicts between expressions of liberty and state policy. In Liberty of Conscience Nussbaum construes the conflict between piety and secular law as an Antigone Dilemma (Nussbaum, 2008, pp. 116-120). That framing is apt, because the conflict is a result of perceived irreconcilable demands on a person's conscience. There can be non-religious versions of this dilemma too. A non-religious citizen might object to mandatory flag salutes on grounds that mass loyalty oaths compelled by the state are an affront to freedom of thought. A respect conception of toleration will favour minimizing Antigone Dilemmas either by eliminating policies that create them, or by granting exemptions to accommodate those with conscientious objections to legitimate state policy. There are hard questions about limits. Yet as a matter of framing liberal toleration, Nussbaum's position as well as 
Shiffrin's thinker-based approach to freedom of thought represent examples of how liberty is a basis for the respect conception of toleration.

Stated as a general view that ranges across conceptions of liberalism the respect conception, "proceeds from a morally grounded form of mutual respect on the part of the individuals or groups who exercise toleration" (Forst, 2013, p. 29). Citizens and government are tolerant when they permit activities protected by political liberties such as religious freedom, freedom of association, freedom of thought, and freedom of expression. Some liberals will put more emphasis on non-interference as the basis for political liberty; others will emphasize a principle of equal liberty of all compatible with liberty for each; some will invoke the idea of a right to justification; yet all liberal positions on toleration will place political liberty at the centre.

\section{Toleration and Equality}

Some forms of identity standout because they correlate highly with inequality. Though not an exhaustive list, the following are familiar examples: culture, religion, ethnicity and class. Inequalities that correlate with these forms of identity may be material, symbolic, social or political. For members of some groups, inequalities will be manifest in more than one or even all of these forms. Some liberal political philosophers claim that a liberal view on toleration should take status inequalities seriously (Galeotti, 2002.

In an early defence of multicultural liberalism Charles Taylor (1994) once advanced the claim that recognition is the appropriate attitude towards diversity, partly on grounds that every culture is centred on some intrinsic values that are unique to that culture. Respect for the value of diversity is another consideration. On Anna Galeotti's view, "toleration as recognition does not imply taking sides" (Galeotti, 2019, p. 6). Rather it offers "a public declaration that a given practice ... is a legitimate option among others" (Galeotti, 2019, p. 6). A third consideration that has been develped in greater detail by those defending multicultural liberalism emphasizes ways that cultural and other identities matter to those who affirm such identities. For example, Alan Patten's equal recognition approach is based on the principle that persons should have a fair opportunity to pursue meaningful conceptions of the good life (Patten, 2014).

Some status inequalities might be judged to correlate with choices under fair background conditions, such as choosing membership in a reclusive religious community when other options are open. A citizen who elects to remain a committed Old Order Amish in the US will in doing so give up a number of opportunities ranging from university education, a lucrative career in cybersecurity, among other pursuits that in principle are open to everyone. She will also be seen as a kind of outsider by many members of the majority culture. Provided this affiliation is chosen, it might seem that all things considered her material and political status is not objectionable.

However, the politics of tolerating minority groups is often far more complicated. When status inequalities correlate with patterns of discrimination emphasizing a liberty right to choose membership in the group whose members have "opted out" of options is disrespectful. Consider those who insist that sexual orientation "is a choice", not because they celebrate liberty and toleration, but because they want to discriminate. Religious bigotry is sometimes expressed on a similar basis. A person might be convinced that their anti-Muslim bias is motivated by a judgment that, since someone chooses to be a Muslim, it is acceptable to express anti-Muslim views. If an "anti-Muslim" judgment is about a religious doctrine and not a person's identity in any fundamental sense, so the person 
reasons, this is not a form of objectionable prejudice. An appropriate reply to this is "not so fast!" Reasons to challenge that view include that the colour of a person's skin will often determine whether a judgment of anti-Muslim bias is made; whether a Muslim is a woman and if so whether she wears a headscarf may trigger a judgment of anti-Muslim bias; and many other factors ranging from nationality to language can influence the antiMuslim bias expressed by those who claim they are simply making a judgment about a doctrine and not a person. In actuality intolerance of persons is often conflated with value judgments about a doctrine.

An American Muslim has a place in the collective imaginary of American national identity that is very different from that of a Protestant Christian. Despite an official state policy prohibiting religious discrimination many opportunities will be more difficult to realize for an American Muslim. If she wears a hijab, has dark skin or is a recent immigrant, these factors will affect her status. If she is outspoken or critical of state policy, her loyalty may well be questioned. There is a clear double standard here: white Protestant citizens can engage in far more forms of dissent without their loyalty being called into question. Many Americans believe the proposition, "we are a Christian nation". This belief is often expressed in a way that equivocates between a merely demographic statement and a normative claim about equality in status. This obfuscation is sometimes intentional: "we are a Christian nation" is a familiar way to mark those who do not squarely fit into the imagined national identity with a kind of outsider status, regardless of nationality. From a purely legal standpoint, citizenship might confer equal status, but politics and culture often deviate from that legal standpoint. The toleration as recognition approach may be better able to address this issue than a traditional respect conception.

Political discourse in the service of a majoritarian identity, real or imagined, usually downplays the many effects of unequal status. Unequal status can undermine what Rawls termed, "the social bases for self-respect" (Rawls, 1996). Whether the idea of liberal neutrality associated with the respect conception of toleration is objectionably differenceblind is one issue taken up by proponents of a recognition approach to toleration.

According to Galeotti the standard liberal view on toleration, "makes it impossible to recognize the issue of unequal membership" and thus, "all differences become equally invisible from a political standpoint" (Galeotti, 2002, p. 67). Toleration as recognition is motivated in part to address status inequalities. Another version of the toleration as recognition approach combines ideas about fairness, such equality of opportunity, and liberty. For example, Patten defends an equal recognition approach (Patten, 2014). On his view, each member of a liberal society should have an equal opportunity for selfdetermination. The site of recognition on Patten's conception is the liberty to pursue conceptions of value or the good under background conditions of fair equality of opportunity.

Proponents of the recognition approach do not reject the idea that liberty is essential to toleration. The tolerant open society will protect the one from the many by standing behind the liberty right to be different. Yet a central question is, how so? Will a tolerant open society remain neutral towards status inequalities, except in clear cases of coercion that violate a non-interference criterion? Or will a tolerant open society also commit to mitigating effects of inequalities in status? There is a morally relevant difference between an effort by a Christian majority to prevent the construction of a mosque - all liberals concur that a tolerant open society will oppose that effort - and the asymmetrical statuses that correlate with majority and minority religious statuses, not just in private but also public domains. Should a liberal conception of toleration focus only on the former? 
Oftentimes there are no easy answers to questions about cases, in part because there are almost always multiple factors in play. For example, past discrimination against a religious minority can be salient to contemporary politics; intergenerational effects of bias can be reflected in state policy; status privileged citizens often resist calls to recognize inequalities in status, and resist efforts to address them even more so; and proxies for bias often serve as tools that permit messaging strategies that affirm a form of bigotry under the guise of something else. Status anxiety among members of a dominant group whose effort to maintain dominance can inspire various forms of intolerance. Any person judged to be a threat to status dominance is a possible target of resentment. White racial resentment in the American context is a paradigm case. Richard Hofstadter (1964) offered a classic formulation of this idea when discussing the American Civil Rights Movement. Moreover, when members of a group that has been subject to intolerance demand better treatment, resentment on the part of those who favour the intolerance, most especially from those who benefit from it in the form of status privilege, is a common response.

Institutions may or may not be complicit in objectionable unequal statuses. Yet even when they are not, equality in status matters across a range of contexts from interpersonal relations, employment opportunities for high status positions and access to political office. A main focus of classical liberal theory is on questions about political authority and the state's role in protecting citizens' political liberty. Yet the power conferred by privileged status benefits some in formal and informal contexts, sometimes irrespective of state policy. Offices and opportunities, ranging from official positions in government to opportunities to pursue various careers, may be more or less open to a citizen in virtue of her religious identity. Should a tolerant society seek means to ensure that if persons pursue a permissible conception of the good this does not correlate with status inequalities? And if so, by what means?

Critics of the recognition approach sometimes argue that a liberal conception of toleration should not compromise on the idea that liberty is the primary basis for toleration. Those who defend a recognition approach to toleration can respond by pointing out that one ought not to have a diminished status in the political community merely because of one's membership in a cultural or religious group.

Patten's equal recognition approach is one way to take on the challenges posed to the toleration as recognition approach that emphasize an individual right to liberty. On his view, liberty is affirmed in the idea of an equal right to opportunities for self-determination (Patten, 2014). Equality is affirmed in the idea of an equal treatment standard that can measure whether opportunities for self-determination are fairly maintained. There is room for debate about adopting a distributive model for toleration, one that integrates the idea of fair equality of opportunity with the idea of liberty rights to religious freedom, freedom of association, and freedom of expression (Jones, 2017). Yet if we grant the principle of fair equality of opportunity for self-determination, we can see how it supports an idea of toleration that meets what would otherwise be the competing desideratum of the respect and recognition conceptions of toleration.

\section{Ethical Pluralism and Toleration}

Most work by liberal political philosophers focuses on value pluralism within a western religious, political, and cultural context. Classical liberals such as Locke and Mill framed questions about toleration in order to address that perspective. Some recent developments in comparative philosophy or what is sometimes called global philosophy point to a 
different set of issues for a liberal view on toleration (Hashemi, 2009). Some of this work highlights pluralism across traditions, for example traditions that affirm an individualistic view of political morality and traditions that affirm collectivistic conceptions of political morality (Buchanan, 2013; Kim, 2014). This raises a number of challenging questions, including, are there reasonable yet incompatible conceptions of political morality, some of which are collectivistic and non-liberal?

Those with expertise in Islamic political philosophy (March, 2019), Chinese political philosophy (Angle, 2012), or collectivistic conceptions of political morality that inform ideas about human rights (Buchanan, 2013), have offered interesting proposals on the prospects for liberal political values in these contexts. I draw on some of their work here not to add to their scholarship to but to examine questions for liberal toleration in comparative perspective.

In his recent book on ideas about political authority and sovereignty within modern Islamic political thought Andrew March (2019) notes that within Sunni Islam an influential view holds that God authorizes the Muslim community - Umma - to form an Islamic democracy. In a formulation of the relation between religious and political authority that resembles a Lockean view one of the intellectuals who informed Kemalism in the early Turkish Republic, Ziya Gokalp, proclaimed, "God's representative (on earth) is the people. ... Authority belongs to the people and not to the Sultan. . . To it belongs all power - legislative, judicial, and executive" (March, 2019, p. 38). Nader Hashemi (2009) examines contemporary debates among Shia political thinkers who stake out positions ranging from a defence of secular government, Islamic democracy, and theocracy. For example, Hashemi considers an interesting parallel between the Locke-Filmer debate on political authority and contemporary Iranian political thinkers (Hashemi, 2009, pp. 67102). Those who advocate a secular conception of political authority are more likely to favour toleration for Baha'i and others who face discrimination. Stephen Angle (2012) explores ways that within Confucian thought leadership is conferred by characteristics of a virtuous ruler whose moral authority to rule depends on having the right characteristics.

Pluralism across states raises a different set of questions for liberal toleration than does pluralism within states. For example, Canada and the US have minority cultures and religions that embrace collectivistic and non-liberal values, yet the dominant political cultures reflect a broadly liberal perspective on individual liberty. There are significant differences between the minority status of someone who affirms liberalism in a non-liberal society and someone who affirms an illiberal view in a liberal society. A Lockean liberal living in the Chinese Republic does not have the same status under law as an Old Order Amish living in the USA. One obvious difference is that in one case a person might be exercising religious liberty, whereas in the other, a person is denied such liberty.

In an interesting examination of Protestant and Hindu religious doctrine and practice Spinner-Halev (2005) notes that for most practising Hindus belonging to a practice is far more central than belief. Ritual is primary. Religious conscience is secondary. Liberal ideas about liberty and respect for conscience largely reflect the legacy of the impact of Protestant Christianity on early liberal thought.

Belonging precedes belief for many religious persons, whatever the religious tradition and wherever it is practised. It is better to refer to degrees of individualism and degrees of collectivism in religious self-understanding. However, as a matter of doctrine, the priority of inner conviction over outward ritual plays a special role in Protestant Christianity. There is a clear connection between this Protestant conception of religious doctrine and the classical liberal liberty and toleration. A "thinker-based" approach to liberty, for example, 
places emphasize on inner conviction and individual agency. By contrast rituals at the heart of a collective identity, religious or non-religious, may be understood as more basic, and a more important source of values and human identity.

Many liberals will bristle at the thought of a communal "ritual-based" alternative to the thinker-based approach of Shiffrin. Yet that there are so many examples of collectivistic conceptions of value, including political morality, at odds with the value individualism central to liberalism raises an interesting challenge for liberal positions on toleration. It is one thing to ask, what is the most appropriate conception of toleration for citizens in a diverse society who agree that every citizen is free and equal? That question is challenging enough even when diverse citizens whose views are mutually intelligible to one another struggle to find shared bases for a liberal conception of toleration. Pluralism within and pluralism across traditions raise different kinds of challenges. One example of pluralism within a tradition is competing conceptions of liberal values, including debates over how to understand liberty and equality. Pluralism across traditions includes individualistic and collective conceptions of political morality that divide those who mostly agree with liberal political morality and those who do not. Of course, there are illiberal doctrines defended within the context of dominant liberal traditions as well as liberal doctrines defended in the context of dominant illiberal traditions.

Open mindedness about conceptions of toleration need not entail affirming toleration without limits. Yet open mindedness about practices of toleration should be at the centre of liberal theories of toleration. Judgements about the basic moral convictions deemed essential to liberty and equality are frequently negotiated by people who disagree on some fundamental points. Taking the widely discussed options on pluralism within liberal societies and rethinking them in comparative perspective is one way to develop this idea. Another is to consider conceptions of toleration from within non-western traditions of political morality. The pursuit of these and other options should be embraced rather than resisted by liberal political philosophers.

Lastly, an important issue that needs to be considered in this context is how dialogue across traditions is framed. There can be a chauvinism on the part of liberal political philosophers who assume that productive dialogue will result in a Chinese political philosopher embracing liberal values without mutual influence across traditions. Yet why should the influence be one-way? It is likely that there are forms of liberal toleration yet to be imagined, including those that reflect mutual influence across traditions.

\section{Conclusion}

The perspectives on toleration considered in this chapter highlight illiberal and liberal practices of toleration, cases where liberal states are sometimes more intolerant than nonliberal states, as well as different formulations of toleration within liberal political philosophy. Having a taxonomy of conceptions of toleration can clarify a wide range of practices within both liberal and non-liberal states. This is helpful for at least two reasons. First, whether the best conceptions of toleration will be adapted to liberal political morality is a separate question from which practices qualify as a form of toleration. Second, the paradigm cases that liberal political philosophers examine are important, yet also limited. There are both global and historical perspectives on toleration that can inform how we think about toleration. Why limit cases and examples of toleration to modern or to western states unless we are offering a proposal for toleration that applies to just those contexts? 
Error! No text of specified style in document. Liberalism and Toleration

Whether theories of toleration offer helpful perspective on moral progress, reform or diffusing political conflicts will depend in part on open mindedness about how states and persons can realize practices of toleration. A selection bias informs many liberal accounts of toleration: these accounts focus on cases in the American or European context. The headscarf debates in Europe or the religious exemptions debate in the US are important cases for thinking about toleration. Thinking about political and moral dimensions of toleration from just these perspectives comes at the risk of introducing a parochial bias in liberal views on toleration. It also encourages political philosophers to overlook biases in how they think about the political values that inform their understanding of toleration. Consideration of non-liberal practices of toleration and the pluralist challenge can help us appreciate the limitations of standard positions.

To conclude, a consideration of various forms of pluralism and their implications for toleration might lead to more or less radical positions. Chandran Kukathas (2017) has recently argued for a conception of toleration without limits, a conception informed by skepticism about attempts to justify limits to toleration with the harm principle, a basic right to justification, or some other standard. That is one possible outcome. Another option is to defend a kind of moral minimalism as a basis for toleration. Forst defends such a view when he claims, "No other values or norms except the principle of justification itself can provide the foundation of . . toleration" (Forst, 2013, p. 400). A comparative or global philosophy approach might lead to third outcome, one that affirms value pluralism in a way that supports multiple conceptions of toleration. The main focus of this chapter has been on liberalism and toleration, yet the central ideas are presented with the recognition that there are many more questions to examine than have hitherto been adequately addressed.

\section{References}

Angle, S. (2012). Contemporary Confucian Political Philosophy. Cambridge: Polity Press.

Balint, P. (2017). Respecting Toleration: Traditional Liberalism and Contemporary Diversity. New York: Oxford University Press.

Buchanan, A. (2013). The Heart of Human Rights. New York: Oxford University Press.

Forst, R. (2013). Toleration in Conflict: Past and Present. Trans C. Cronin. Cambridge: Cambridge University Press.

Forst, R. (2017). Toleration. In: Stanford Encyclopedia of Philosophy. Edward N. Zalta (ed.), URL $=<$ https://plato.stanford.edu/archives/fall2017/entries/toleration/>.

Galeotti, A. (2002). Toleration as Recognition. Cambridge: Cambridge University Press.

Galeotti, A. (2019). Rescuing Toleration. Critical Review of International Social and Political Philosophy, pp. 1-22. [online] Available at: https://doi.org/10.1080/13698230.2019.1616882 [Accessed 28 Apr. 2020].

Hashemi, N. (2009). Islam, Secularism, and Liberal Democracy: Toward a Democratic Theory of Muslim Societies. New York: Oxford University Press.

Hofstadter, R. (1964). The Paranoid Style of American Politics. Harper's Magazine, Nov.

Jacobs, J. (2017). Xinjiang and the Modern Chinese State. Seattle, WA: University of Washington Press.

Jones, P. (2017). Religious Exemption and Distributive Justice. In: C. Laborde and A. Bardon, eds., Religion in Liberal Political Philosophy. Oxford: Oxford University Press, pp. 163-176.

Kim, S. (2014). Confucian Democracy in East Asia: Theory and Practice. Cambridge: Cambridge University Press. 
Error! No text of specified style in document. Liberalism and Toleration

Kukathas, C. (2017). Toleration Without Limits: A Reconstruction and Defense of Pierre Bayle's Philosophical Commentary. In: C. Laborde and A. Bardon, eds., Religion in Liberal Political Philosophy, Oxford: Oxford University Press, pp. 262-274.

March, A. (2019). The Caliphate of Man: Popular Sovereignty in Modern Islamic Thought. Cambridge, MA: The Belknap Press of Harvard University Press.

Mill, J. S. (1978). On Liberty, 8th ed. Indianapolis, IN: Hackett Publishing.

Nussbaum, M. (2008). Liberty of Conscience: In Defense of America's Tradition of Religious Equality. New York: Basic Books.

Patten, A. (2014). Equal Recognition Equal Recognition: The Moral Foundations of Minority Rights. Princeton, NJ: Princeton University Press.

Rasmussen Reports. (2013). 68\% Think School Children Should Say Pledge Allegiance Every Morning. [online] Available at: www.rasmussenreports.com/public_content/lifestyle/general_lifestyle/september_2013/6 8_think_school_children_should_say_pledge_of_allegiance_every_morning [Accessed 28 Apr. 2020].

Rawls, J. (1996). Political Liberalism, expanded ed. New York: Columbia University Press.

Schouten, G. (2019). Liberalism, Neutrality, and the Gendered Division of Labor. Cambridge: Cambridge University Press.

Shiffrin, S. (2011). A Thinker-Based Approach to Freedom of Speech. Constitutional Commentary, 21, pp. 283-307.

Shiffrin, S. and Blasi, V. (2009). The Story of West Virginia Board of Education v. Barnette. In: M. Dorf, ed., Constitutional Law Stories, 2nd ed. St Paul, MN: Foundation Press, pp. 409453.

Smith, D. (2015). Religious Persecution and Political Order in the United States. Cambridge: Cambridge University Press.

Spinner-Halev, J. (2005). Hinduism, Christianity, and Liberal Religious Toleration. Political Theory, 33(1), pp. 28-57.

Taylor, C. (1994). The Politics of Recognition. In: A. Guttman, ed., Multiculturalism. Princeton, NJ: Princeton University Press, pp. 25-75.

West Virginia State Board of Education v Barnette. (1943). 319 US 624. 